This article was downloaded by: [B-on Consortium - 2007]

On: 27 July 2009

Access details: Access Details: [subscription number 908038079]

Publisher Taylor \& Francis

Informa Ltd Registered in England and Wales Registered Number: 1072954 Registered office: Mortimer House, 37-41 Mortimer Street, London W1T 3JH, UK

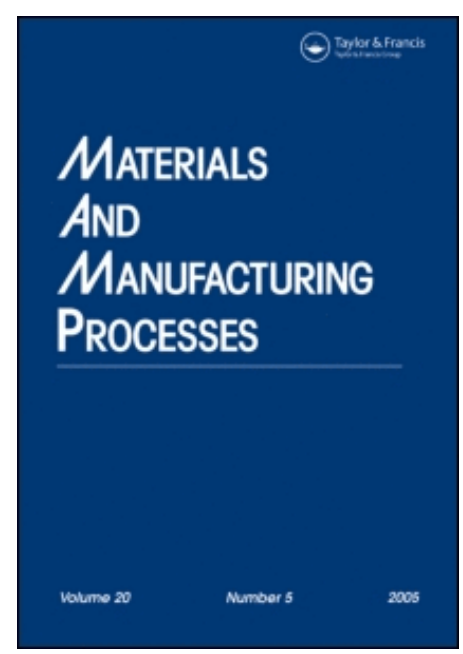

Materials and Manufacturing Processes

Publication details, including instructions for authors and subscription information:

http://www.informaworld.com/smpp/title content=t713597284

\title{
Orientalizing Artifacts from Fraga dos Corvos Rock Shelter in North Portugal
}

E. Figueiredo abc; J. C. Senna-Martinez ${ }^{\text {; }}$ R. J. C. Silva c; M. F. Araújo a

${ }^{a}$ Instituto Tecnológico e Nuclear (ITN), Sacavém, Portugal ${ }^{\mathrm{b}}$ Departamento de Conservação e Restauro, Faculdade de Ciências e Tecnologia, Universidade Nova de Lisboa, Monte de Caparica, Portugal ${ }^{\circ}$ Centro de Investigação de Materiais (CENIMAT/I3N), Faculdade de Ciências e Tecnologia, Universidade Nova de Lisboa, Monte de Caparica, Portugal ${ }^{\mathrm{d}}$ Centro de Arqueologia (Uniarq), Faculdade de Letras, Universidade de Lisboa, Lisboa, Portugal

Online Publication Date: 01 September 2009

To cite this Article Figueiredo, E., Senna-Martinez, J. C., Silva, R. J. C. and Araújo, M. F.(2009)'Orientalizing Artifacts from Fraga dos Corvos Rock Shelter in North Portugal',Materials and Manufacturing Processes,24:9,949 - 954

To link to this Article: DOI: $10.1080 / 10426910902982508$

URL: http://dx.doi.org/10.1080/10426910902982508

\section{PLEASE SCROLL DOWN FOR ARTICLE}

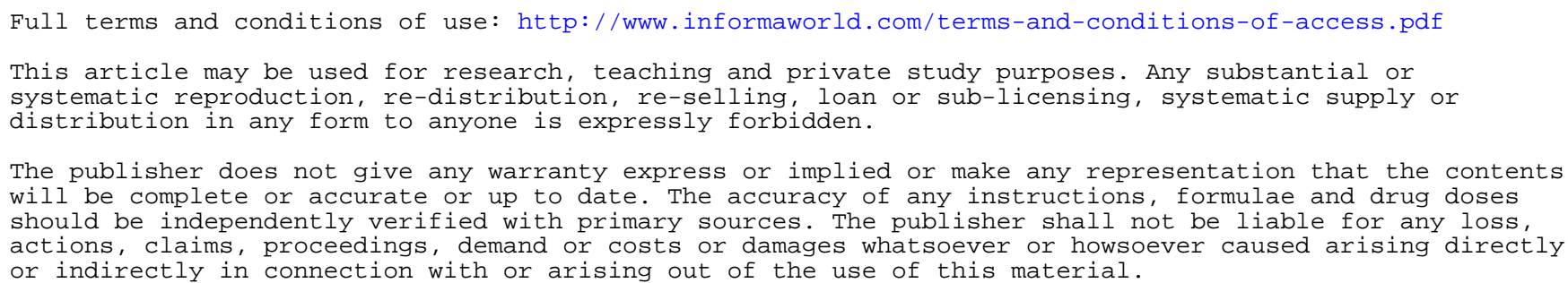




\title{
Orientalizing Artifacts from Fraga dos Corvos Rock Shelter in North Portugal
}

\author{
E. Figueiredo ${ }^{1,2,3}$, J. C. Senna-Martinez ${ }^{4}$, R. J. C. Silva ${ }^{3}$, and M. F. Araújo ${ }^{1}$ \\ ${ }^{1}$ Instituto Tecnológico e Nuclear (ITN), Sacavém, Portugal \\ ${ }^{2}$ Departamento de Conservação e Restauro, Faculdade de Ciências e Tecnologia, Universidade Nova de Lisboa, \\ Monte de Caparica, Portugal \\ ${ }^{3}$ Centro de Investigação de Materiais (CENIMAT/I3N), Faculdade de Ciências e Tecnologia, \\ Universidade Nova de Lisboa, Monte de Caparica, Portugal \\ ${ }^{4}$ Centro de Arqueologia (Uniarq), Faculdade de Letras, Universidade de Lisboa, Lisboa, Portugal
}

\begin{abstract}
An unusual set of metallic artifacts with orientalizing character, attributed to a late period of the Late Bronze Age (LBA), was found in a shelter in Northern Portugal. Conventional and micro-energy dispersive X-ray fluorescence (XRF) analyses have been performed to determine the metal composition. The microstructures of some artifacts have also been studied under optical and scanning electron microscope (SEM). The results show that most of the items are made of a copper-tin alloy with low lead content and show a recrystallized grained microstructure.
\end{abstract}

Keywords Archaeometallurgy; Bronze; Iberian Peninsula; Late Bronze Age; Microstructure.

\section{INTRODUCTION}

Studies on Late Bronze Age (LBA) metal artifacts (dated between the end of the 2 nd millennium to the early 1 st millennium B.C.) showed that the bronze composition used in the Iberian Peninsula contains $\mathrm{Pb}$ as a minor constituent, with percentages regularly $<1 \%$. This is significantly distinct from the alloy used in other "Atlantic" areas, such as the English and French territories, where the $\mathrm{Pb}$ content can regularly reach values up to $10 \%$ [1]. All artifacts from Ria de Huelva, southern Spain, and those from central Portuguese sites, such as Santa Luzia, Canedotes, Sernancelhe, Monte do Frade, Alegrios, and Moreirinha [2-5] show tin values between $8-14 \%$, and no or very low $\mathrm{Pb}$ (Fig. 1). This metal type shows more similarities with that of Mediterranean areas. However, the bronze employed in the rest of the Mediterranean in the LBA (or, in the contemporary Eastern Mediterranean, in the Iron Age), shows regularly a lower Sn content (7-9\% or less) and commonly a $\mathrm{Pb}$ content of $1-3 \%[1,6]$.

Higher variations in $\mathrm{Sn}$ content and higher $\mathrm{Pb}$ content only became common in the artifacts of the Iberian Peninsula at the beginning of the Iron Age. The transition from Bronze to Iron Age happens, at least in the south of the Iberian Peninsula, with the beginning of the Orientalizing period. In the Northern Iberian regions, the Orientalizing influences are not as evident as in the south; therefore, the LBA continues here until the mid-first millennium. The studies on Orientalizing metal artifacts, related to the

Received January 10, 2008; Accepted November 30, 2008

Address correspondence to E. Figueiredo, Instituto Tecnológico e Nuclear, Estrada Nacional 10, 2686-953 Sacavém, Portugal; Fax: +351219946185; E-mail: elin@itn.pt presence of Phoenicians on the Iberian coasts, are much scarcer than those on the earlier Atlantic tradition.

Analyses of metallic items from the Phoenician site of Almaraz (on the western coast of Portugal) determined alloys with low $\mathrm{Sn}$ and variable $\mathrm{Pb}$ contents [7], which can be easily distinguished from the previous alloys used during the LBA.

Analyses of numerous metallic items from the orientalizing site of Cancho Roano (southwest of Spain, dated to the middle of the first millennium B.C.) showed erratic alloy compositions, with highly variable concentrations of $\mathrm{Sn}$ and $\mathrm{Pb}$ [8].

More recent studies, concerning orientalizing sites dated to the 7-6th century B.C., as El Palomar and Medellín (Extremadura, Spain), determined $\mathrm{Cu}-\mathrm{Sn}$ alloys with percentages and impurity patterns quite different from those of Cancho Roano (which has a later chronology). In both sites, the majority of the items were of bronze with $<2 \%$ $\mathrm{Pb}$; a small number of bronze with a high amount of $\mathrm{Pb}$ (mainly large sized objects); and a few pieces were made of unalloyed copper [9].

During the archaeological excavations in a rock shelter at Fraga dos Corvos site (Macedo de Cavaleiros) in northern Portugal, a number of metallic items of orientalizing type were found. The group of artifacts comprises a double resort fibula, two needles, a flat pendant, decorated on both sides with dotted lines which form star-shaped motifs, and a cosmetic spatula. Further eight bar-shaped fragments (comprising possibly fragments of a bracelet and a ring) and one metallic nodule were found (Fig. 2).

Typologically, the group of artifacts has a Mediterranean character which suggests a Phoenician origin or, at least, a strong influence from the southern areas of the Iberian Peninsula. Additionally, the decoration of the pendant finds 


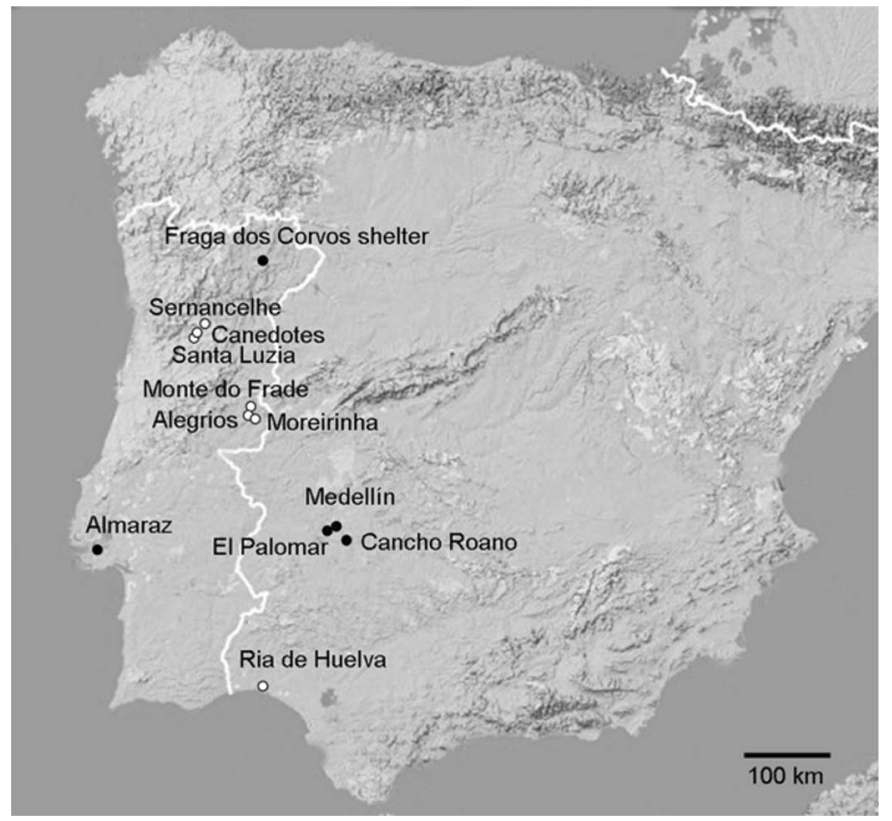

FIGURE 1.-Location of the mentioned archaeological sites in which artifacts show strong Atlantic typological features (white dots) and orientalizing typological features (black dots) in the Iberian Peninsula.

close parallels in the orientalizing graffiti on the grey ware of Medellín [10].

The items were found in disturbed layers; however, the typology of the objects suggests that they are part of one set of artifacts, probably of a funerary deposit belonging to a late period of the LBA [11].

\section{EXPERIMENTAL}

All items were at first, without surface preparation, submitted to energy dispersive X-ray fluorescence (EDXRF) analyses to identify the type of alloy(s). These results were
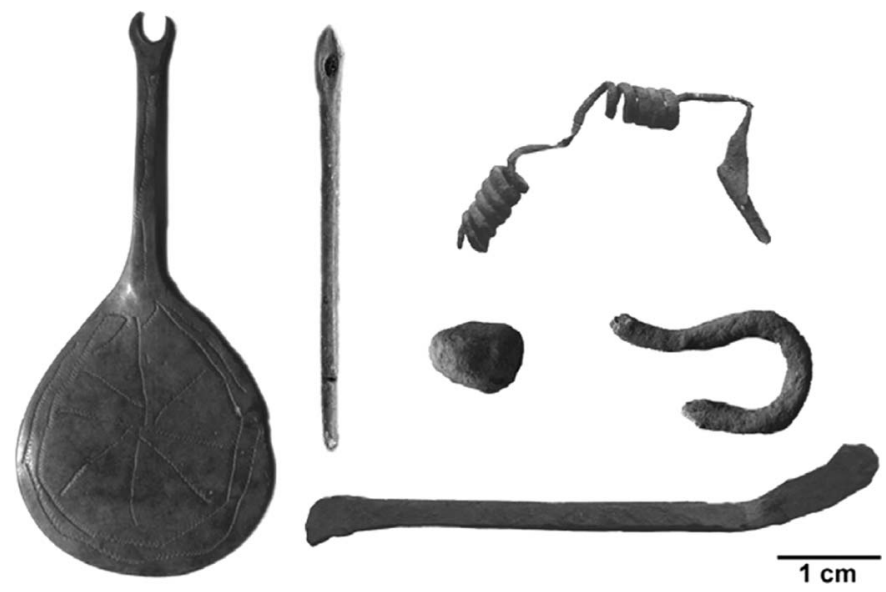

FIGURE 2.-Image of some of the artifacts found in Fraga dos Corvos shelter. From left to right, top to bottom: pendant FC-215; needle FC-188; fibula FC-181; nodule FC-474; Tartessian belt hook fragment FC-473; and cosmetic spatula FC-361. interpreted as semiquantitative, because of the presence of superficial corroded layers. Indeed, several phenomena may induce changes on the overall composition of the exposed area of the artifacts, i.e., superficial decuprification which leads to enhanced concentrations of the other alloy elements [4] or enrichment of other elements in soil (i.e., Fe) easily incorporated in corrosion layers.

The EDXRF analyses were carried out in a Kevex 771 spectrometer, with secondary targets that allow the optimization of the analytical conditions. Certified reference materials phosphor bronzes from the Burial of Analysed Samples LTD and leaded bronzes from the BNF Metals Technology Centre were used to calibrate the spectrometer. Detailed description of the equipment [12], and quantification procedures were described elsewhere $[3,4]$.

Subsequently, small samples were taken for metallographic examination from three bar fragments, the ring(?) fragment, a bracelet(?) fragment and from the metallic nodule. All samples were mounted in cold mounting epoxide resin and polished with $\mathrm{SiC}$ abrasive paper and diamond suspension (up to $1 / 4 \mu \mathrm{m}$ ) following the usual procedure.

On three more artifacts (needle FC-457, cosmetic spatula FC-361, and tartessian belt hook fragment FC-473) a small area of the surface was cleaned from superficial corrosion and polished (without sampling). All items were examined by optical microscope (OM) in bright field (bf), polarized light (pol), and dark field (df), both in unetched and etched conditions. The etching was carried out by using an aqueous ferric chloride solution.

Micro-EDXRF analyses were also conducted on all cleaned and polished areas, for the elemental determination of the alloy composition. These analyses were performed by using an ArtTAX Pro spectrometer, with a low-power $\mathrm{X}$-ray tube with a molybdenum anode, and a set of polycapillary lenses generating a microspot, lower than $100 \mu \mathrm{m}$ in diameter, of primary radiation.

The quantification analyses were carried out by using WinAxil software. The calibration was done by using the same reference materials employed for EDXRF. The quantification procedures were recently described $[3,4]$.

Additionally, micro-EDXRF analyses were also conducted on two artifacts (the needle FC-188 and the fibula FC-181) on an area with a recent fracture, and therefore, free of superficial corrosion layers.

A selected sample (FC-206 bar fragment) was also observed under SEM, model Zeiss DSM 962, with secondary electron detector (SE), backscattered electrons detector (BSE), and energy dispersive spectrometer (EDS) from Oxford Instruments model INCAx-sight with an ultrathin window. The analyses and examinations carried out on the artifacts are listed in Table 1.

\section{Results AND Discussion}

The EDXRF analyses allowed the identification of the alloy employed for the artifacts: all items, with exception of the Tartessian belt hook fragment FC-473 which is made of copper with $\mathrm{Sn}$ and $\mathrm{Pb}$ as minor elements, were made of bronze $(\mathrm{Cu}-\mathrm{Sn})$, in most cases with some $\mathrm{Pb}$. 
TABLE 1.-Analyses of studied metal artifacts.

EDXRF Micro-EDXRF OM SEM-EDS

Pendant FC-215

Fibulae FC-181

Needle FC-188

Needle FC-457

Cosmetic spatula FC-361

Bar frag. FC-215

Bar frag. FC-206

Bar frag. FC-208

Ring(?) frag. FC-120

Bracelet(?) frag. FC-364

Bracelet(?) frag. FC-362

Tartessian belt hook frag. FC-473

Metal plate FC-475

Nodule FC-474

* On the area prepared for metallographic examination.

${ }^{* *}$ On a recent fracture surface.

The metallic nodule FC-474 is the only object which shows a $\mathrm{Pb}$ content higher than the Sn content (Table 2).

The micro-EDXRF results allowed the assessment of the metal composition. The ten items analyzed can be grouped in a region with $8-13 \% \mathrm{Sn}$ and $\mathrm{Pb}<2 \%$, and can thus be considered binary bronze alloys (Fig. 3 ).

The needle FC-457 seems to have a highly heterogeneous $\mathrm{Pb}$ distribution (cf. high standard deviation), probably related to the strong intergranular corrosion in the area analyzed (see below metallographic examination), which did not allow to determine the $\mathrm{Pb}$ content with accuracy.

The higher standard deviation determined for the tin contents in FC-188 and FC-181 are probably also related to some internal corrosion, as the micro-EDXRF analyses were done on fractures (Table 1). As the EDXRF analyses suggest, the metallic nodule FC-474, is made of a different alloy. A higher $\mathrm{Pb}$ and a lower $\mathrm{Sn}$ content distinguish it from all other bronzes.

The Tartessian belt hook fragment FC-473, is made of copper with tin and lead as minor elements, and can be considered unalloyed copper.

The cluster of the seven items $(8-13 \% \mathrm{Sn}$ and $<2 \% \mathrm{~Pb})$ represents an alloy with $10.1 \pm 1.5 \% \mathrm{Sn}$ and $1.1 \pm 0.6 \%$ $\mathrm{Pb}$ which can be considered a good quality bronze, with values that do not depart much (possibly a slightly higher $\mathrm{Pb}$ content) from the metallurgical tradition of the Iberian Bronze Age. However, the metallic nodule shows a different composition, with $\sim 5.5 \% \mathrm{Sn}$ and $6 \% \mathrm{~Pb}$. These are not common $\mathrm{Sn}$ and $\mathrm{Pb}$ values for LBA artifacts of the Iberian Peninsula.

The artifacts ensamble has perhaps parallels in the artifacts represented on LBA/Early Iron Age warrior stelae (distributed through the referenced areas). The stelae show figures of (possibly) warriors with their personal items. Frequently represented are fibulae, possibly a mirror with a shape similar to that of the pendant, and small circular items, similar to metallic nodules.

Considering the complete set of artifacts, the compositions show the strongest resemblance with the bronzes from El Palomar and Medellín. Also the typological features of the artifacts from Fraga dos Corvos find close matches among the objects from El Palomar and Medellín.

Metallographic examinations revealed that all items, with the exception of the metallic nodule (FC-474), have recrystallized $\alpha$-grains (twinned) and absence of $\alpha+\delta$

TABLE 2.- Results of EDXRF (a) and micro-EDXRF (b) analyses ( $n$, number of analyses performed on each artifact).

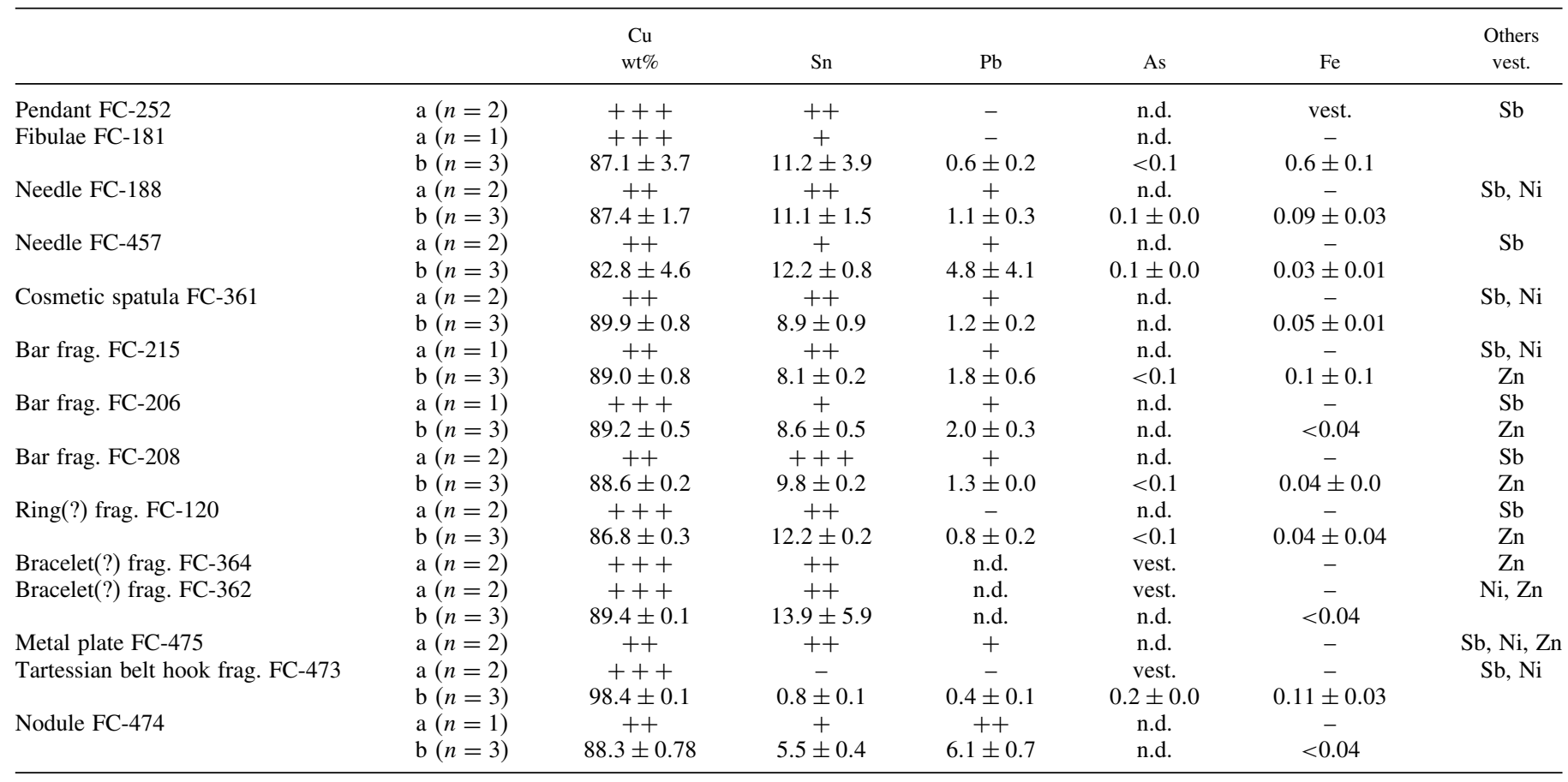

n.d. $=$ not detected.

In EDXRF analyses: (vest.) <1\%; (-) 1-10\%; (+) 10-30\%; $(++)$ 30-50\%; $(+++)>50 \%$; results with influence from corrosion composition. 


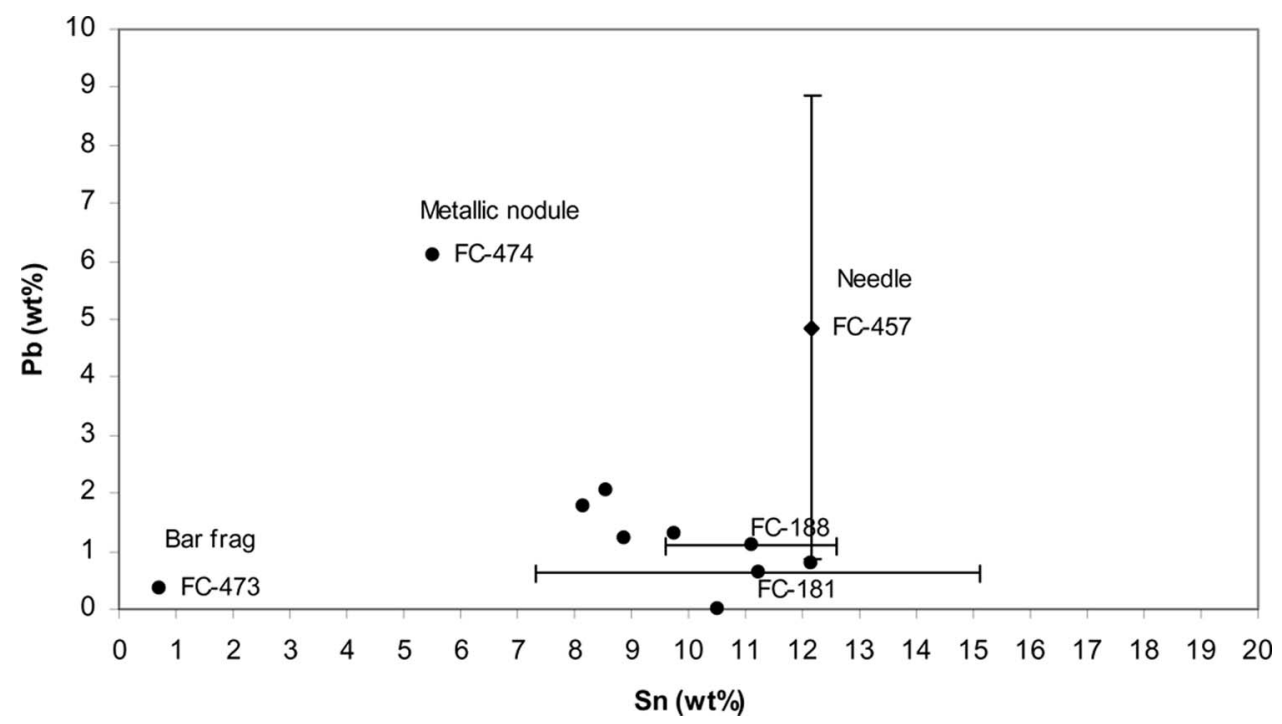

Figure 3.-Plot of the $\mathrm{Sn}$ and $\mathrm{Pb}$ mean contents obtained by micro-EDXRF analyses on the metal bulk of the artifacts. Standard deviations higher than 1 are illustrated.

eutectoid. With normal casting cooling rates, as attained in sand castings, in bronzes with $8-12 \% \mathrm{Sn}$ a biphasic microstructure is expected.

According to the nonequilibrium binary phase diagram for copper-tin metal alloys, the $\alpha$-copper phase would be the only phase in the microstructure of an alloy with up to $15 \%$ Sn when a homogenizing heat treatment, as annealing, is performed. This heat treatment will improve the bronze mechanical properties since it results in the absence of the brittle $\delta$ phase in the final microstructure. In the case of a previous mechanical work a posterior heat treatment would help to recover ductility, by promoting a recrystallization process.

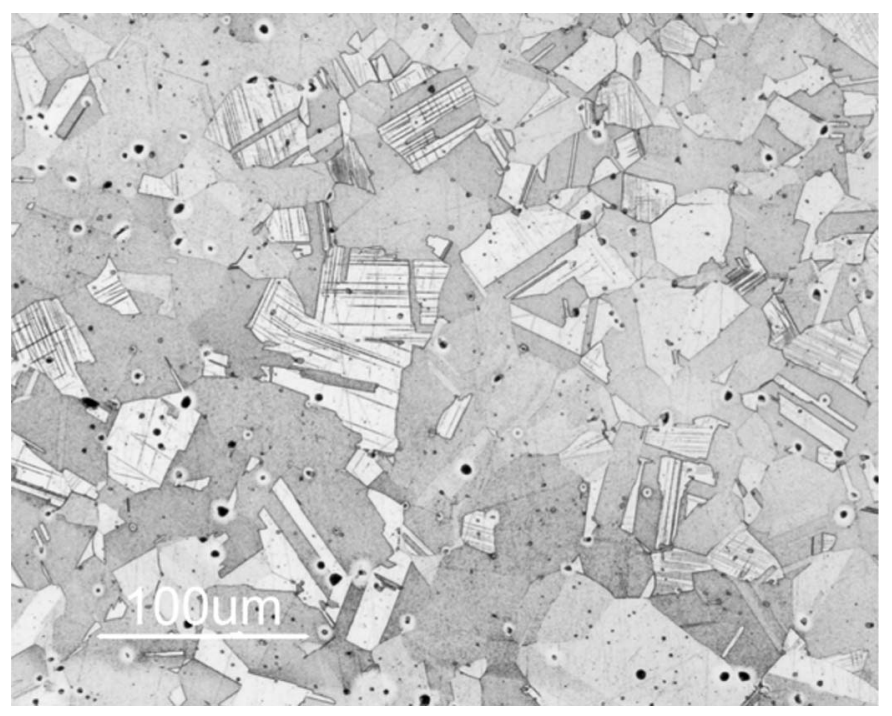

FIGURE 4.-OM image of ring(?) fragment FC-120 revealing $\alpha$-phase recrystallized grains (twinned) with strain bands (etched, BF).
Final mechanical work can increase/adjust the final hardness by a strain hardening effect or it may be carried out for final shape adjustments.

In the examined artifacts, the metalwork consisted in thermomechanical operations, such as cold-forging (to obtain the required shape and harden the metal) followed by annealing (by which the metal became soft again).

On some items, such as bar fragment FC-215, ring fragment FC-120, bracelet(?) fragment FC-362, and needle FC-457, strain bands are also observed. They are probably due to some residual cold work in the final stage of metalwork (Fig. 4).

Intergranular corrosion is present mainly near the surfaces. After the superficial polishing of the needle FC457 , intergranular corrosion along grain boundaries and

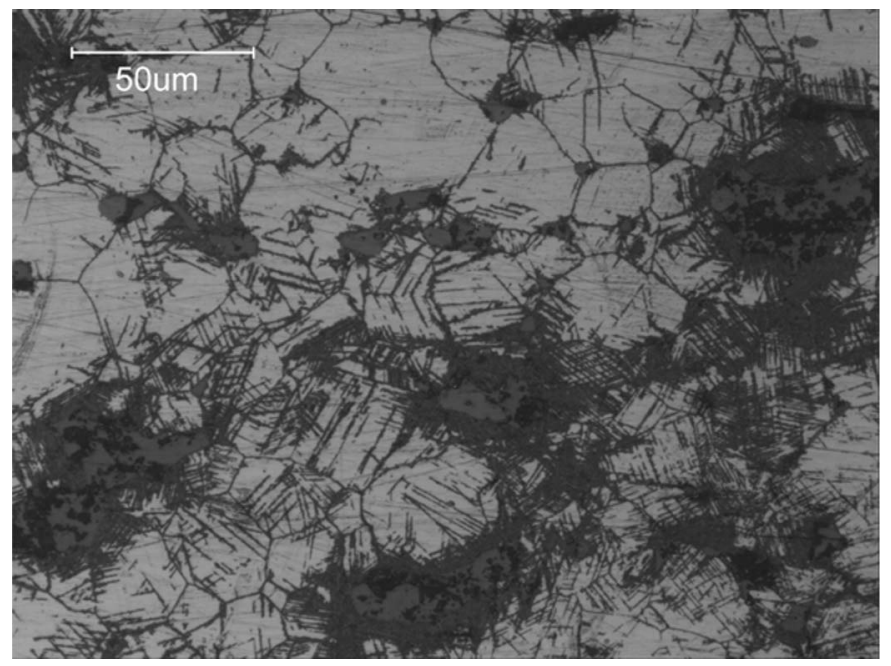

FigURE 5.-OM image of needle FC-457 with inter- and intragranular corrosion (unetched, BF). 
along crystallographic planes (i.e., due to the final cold work) became visible all over the prepared area (Fig. 5).

All microstructures reveal the presence of pores, in various number and sizes, as well as the presence of sulphide inclusions $(\mathrm{Cu}-\mathrm{S})$. The presence of sulphide inclusions, just by itself, does not mean that the ores used in the production of the metal were copper sulphides. If during reduction other minerals rich in sulphur were in contact with the forming metal, sulphur could be incorporated into the metal. Only posterior refining operations would reduce the sulphur content, but the examined microstructures do not seem to indicate that this took place.

Generally, the artifacts with the thinnest sections are also those with the smallest pores and the most distorted sulphide inclusions. The FC-206 bar fragment has the largest cross-section size and is the only item with pores

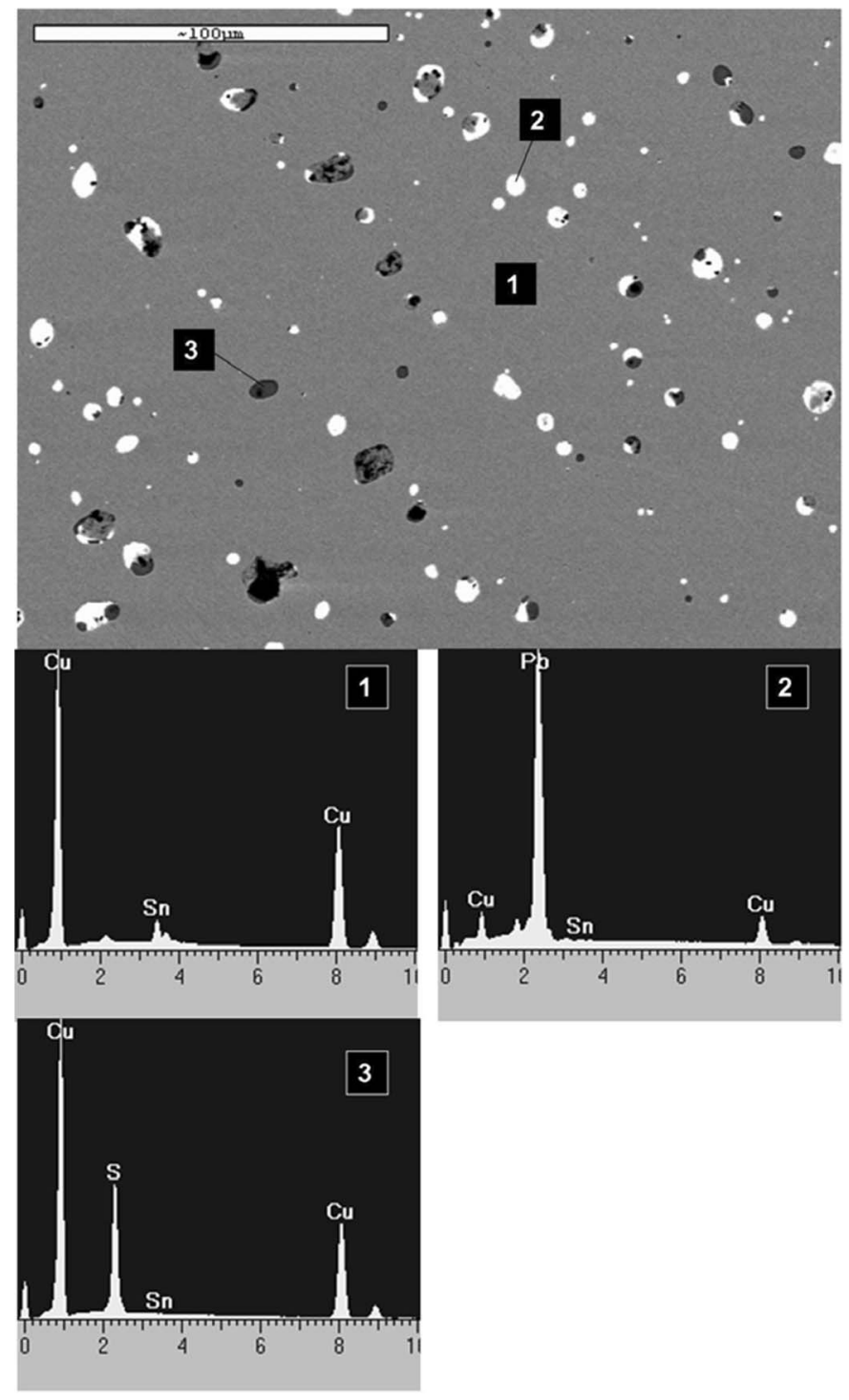

FIGURE 6.-BSE image of bar fragment FC-206. EDS analyses have been performed on: (1) matrix composed by $\alpha$-phase; (2) lead globules; (3) sulphur inclusions.
$>100 \mu \mathrm{m}$. This is also the only fragment with some of the as-cast microstructure morphology (pseudomorphism). All lead globules and sulphide inclusions are aligned and indicate the direction and an estimation of the (secondary) dendritic arms spacing (DAS $\sim 23 \mu \mathrm{m}$ ) which grew during the solidification of the alloy (Fig. 6). Posterior forging did not disturb the alignment.

The FC-474 metallic nodule has an as-cast microstructure with the formation of dendrites which have an arm spacing (DAS) of $\sim 25 \mu \mathrm{m}$. It shows a small amount of interdendritic eutectoid, shrinkage cavities, and $\mathrm{Pb}$ globular or interdendritic forms (Fig. 7).

Metallic nodules can be a result of a reducing operation (transformation from ore to metal), in which they are formed and trapped among the nonmetallic material, or they can be a result of the casting (when metal is poured from the crucible to the mould), if some metal drops out. In the first case, and in the case of a co-smelting process of $\mathrm{Cu}$ and $\mathrm{Sn}$ ores, the resulting nodules would show irregular compositions (S. Rovira, personal communication). In the second case, the composition would be similar to the metal composition of the object(s) produced.

The microstructure can also provide information on the character of the nodule due to a different solidification rate: slow solidification rate for a smelting nodule; fast solidification for a casting nodule. Thus, the microstructure of a smelting nodule should show dendrites with arm spacing larger than that of a casting nodule. Depending on the rate of solidification, and particularly in the second case, it is also possible that no formation of dendrites takes place. Furthermore, depending on the Sn concentration, the formation of the $(\alpha+\delta)$ eutectoid would be favored in the second case, since the cooling would be far from the equilibrium conditions.

In the present study, because of the small size of the metallic nodule, its microstructure does not allow clear conclusions. However, its distinctive composition (different from that of all the other analysed items), suggests that it was produced by smelting.

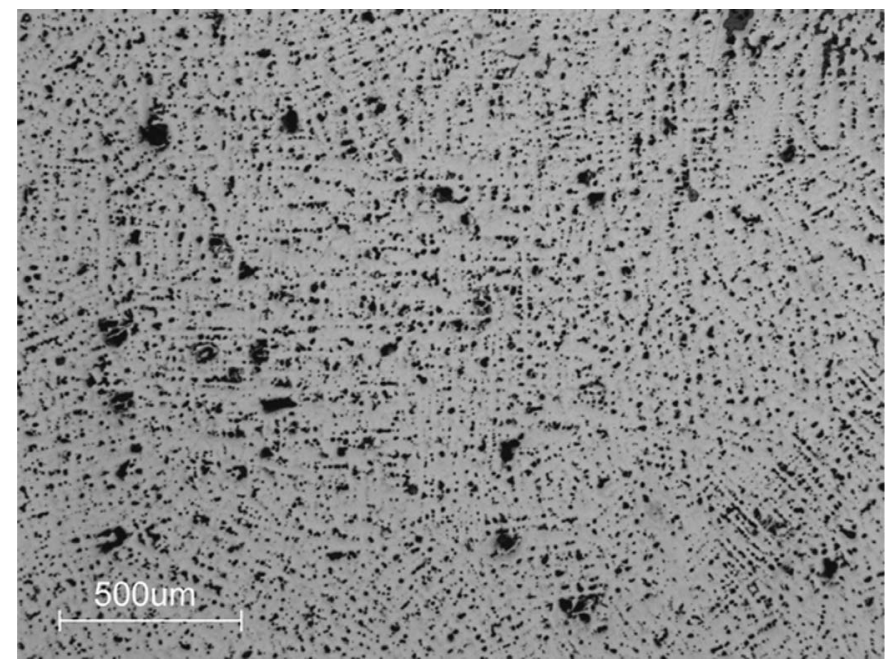

FIGURE 7.-OM image of metallic nodule FC-474 showing dendritic structure (unetched, BF). 


\section{Conclusions}

The stylistic characterisation of the artifacts is supported by the results of the elemental analyses. The metal compositions of the items found in Fraga dos Corvos rock shelter does find close associations with the metallurgical tradition of the orientalising sites of Medellín and El Palomar, where the binary bronzes $(<2 \% \mathrm{~Pb})$ are in the highest proportion, followed by ternary bronzes and unalloyed copper.

The similarities among the pendant decoration and the orientalizing graffiti found on Medellín grey ware do not seem to be casual and apparently confirm the interpretation.

The metallographic observations suggest that the manufacture of small and simple items, as fibulae, bracelet(?), ring(?), cosmetic spatula, belt hook, and bar fragments found in the Fraga dos Corvos hoard, was carried out by working predefined forms, such as bars cast previously in a mould, and further worked to final shape through forging/annealing operations.

Metallographic examinations showed that the annealing treatment was long enough to homogenize the alloy and solubilize any remains of the $\delta$ eutectoid phase resulting in a decrease of brittleness and in an increase of tenacity of the metal.

The rather plain surfaces and simple shapes could be decorated, in a final stage, with a pointed chisel, as in the case of the pendant.

The composition of the metallic nodule suggests that this item might have been produced during a smelting process. The presence of this item among other artifacts at the site also suggests that metal nodules might have been kept and traded as raw material.

\section{ACKNOWLEDGMENTS}

This work has been carried out in the framework of the project POCTI/HAR/58678/2004, Metallurgy and Society in Central Portugal LBA, financed by the Portuguese Science Foundation (FCT). The first author acknowledges the FCT for the SFRH/BD/27358/2006 grant.

\section{REFERENCES}

1. Rovira, S.; Gómez-Ramos, P. L'Atelier du Bronzier en Europe du $\mathrm{XX}^{\mathrm{e}}$ au VIII ${ }^{\mathrm{e}}$ Siècle avant notre Ère. In Actes du Colloque International "Bronze'96", Neuchâtel et Dijon, 1996; Mordant, C., Pernot, M., Rychner, V., Eds.; Comité des Travaux Historiques et Scientifiques et du Centre de Researches sur les Techniques Gréco-Romaines de l'Université de Bourgogne, Paris, 1998.

2. Figueiredo, E.; Araújo, F.; Silva, R.J.C.; Fernandes, F.M.B.; Senna-Martinez, J.C.; Vaz, J.L.I. In Heritage, Weathering and Conservation, Proceedings of the International Conference, Madrid, Spain, June 21-24, 2006; Fort, R., Buergo, M.A., Gomez-Heras, M., Vasquez-Calvo, C., Eds.; Taylor \& Francis: London, 2006.

3. Valério, P.; Araújo, M.F.; Canha, A. EDXRF and microEDXRF studies of Late Bronze Age metallurgical productions from Canedotes (Portugal). Nuclear Instruments and Methods in Physics Research B: Beam Interactions with Materials and Atoms 2007, 263, 477-482.

4. Figueiredo, E.; Valério, P.; Araújo, M.F.; Senna-Martinez, J.C. Micro-EDXRF surface analyses of a bronze spear head: Lead content in metal and corrosion layers. Nuclear Instruments and Methods in Physics Research A: Nuclear Instruments \& Methods in Physics Research 2007, 580, 725-727.

5. Vilaça, R. Metalurgia do Bronze Final da Beira Interior: revisão dos dados à luz de novos resultados. Estudos Pré-Históricos 1997, $V, 123-154$.

6. Giumlia-Mair, A. Copper and copper alloys in the southeastern Alps: An overview. Archaeometry 2005, 47 (2), 275-292.

7. Araújo, M.F.; Barros, L.; Teixeira, A.C.; Melo, A.A. EDXRF study of prehistoric artefacts from Quinta do Almaraz (Cacilhas, Portugal). Nuclear Instruments and Methods in Physics Research B: Beam Interactions with Materials and Atoms 2004, 213, 741-746.

8. Ruiz, I.; Ramos, P.; Rovira, S. Aspectos de la metalurgia orientalizante en Cancho Roano. In Cancho Roano IX. Los Materiales Arqueológicos II; Instituto de Historia: Madrid, Spain, 2003; pp. 195-210.

9. Rovira, S.; Montero, I.; Ortega, J.; Ávila, J.J. Bronce y trabajo del bronce en el poblado orientalizante de "El Palomar" (Oliva de Mérida, Badajoz). Anejos de AEspA 2005, XXXV, 1231-1240.

10. Almagro-Gorbea, M. Inscripciones y grafitos tartésicos de la necrópolis orientalizante de Medellín. Palaeohispanica 2004, 4, $13-44$.

11. Senna-Martinez, J.C.; Ventura, J.M.Q.; Carvalho, H.A.; Figueiredo, E. A Fraga dos Corvos (Macedo de Cavaleiros): Um sítio de habitat da primeira Idade do Bronze em Trás-os-Montes Oriental. A Campanha3 (2005). Caderno Terras Quentes 2006, $3,61-85$.

12. Araújo, M.F.; Alves, L.C.; Cabral, J.M.P. Comparison of EDXRF and PIXE in the analysis of ancient gold coins. Nuclear Instruments and Methods in Physics Research B: Beam Interactions with Materials and Atoms 1993, 75 (1), 450-453. 